\title{
RECENZIÓK
}

BADACSONYI KATALIN TEGZA

\section{Út a kultúrhéroszok korától a jogállamiság felé}

Kormány Attila: A tradicionális és a modern kínai jog A jog fejlödése Kinában a kezdetektöl napjainkig ELTE Eötvös Kiadó Kft., 2018

A jog egy adott társadalom berendezkedésének, egy adott kultúrának markáns részét képezi, az emberek, ezáltal a társadalom viselkedésére hatást gyakorol. Ahogy a társadalom, a szokások, úgy a jog is kultúránként változik, helyi specifikumokkal rendelkezik, a helyi társadalom visszásságaira keres megoldásokat.

A kínai kultúra jogfejlődése markánsan eltér hazánkétól, ugyanúgy, mint az európai országokétól vagy bármely más országétól általánosságban. Ennek ellenére a kínai jog kutatása hazánkban nem terjedt el, a kínai joggal foglalkozó müvek csekély számban lelhetők fel. Ezért számít hiánypótló műnek Kormány Attila könyve. Ez az első, magyar nyelven íródott, a kínai jog fejlődési ívét bemutató könyv a jogi szakirodalomban.

A munka a kínai jogi kultúra iránt érdeklődő, kínai nyelven akár nem is tudó olvasók számára nyújt betekintést a kínai jog fejlődésébe. Hasznos olvasmány lehet mindazok számára, akiket akár a keleti kultúrák, akár a különböző jogrendszerek sajátosságai érdekelnek.

A könyv a bevezetés után három egységre tagolódik. Az első rész a császárkori Kína jogi kultúráját taglalja, a második részben a modern Kína jogi kultúrájáról szóló fejezetek jelennek meg a paradigmaváltások kronologikus sorrendjében, a harmadik rész pedig a szerző összefoglaló gondolatait tartalmazza. Az összegzés listázza azokat a jogi, politikai és ideológiai elveket, amelyek annak ellenére, hogy a múltban fogalmazódtak meg, befolyással bírtak korunk Kínájának állami és jogi irányítására, a társadalom joghoz történő viszonyulására. Emellett röviden összefoglalja a könyv különböző részeiben már ismertetett, a szerző kínai jogi kultúrával kapcsolatos megállapításait. 
A kínai jogfejlődés minden más kultúra jogfejlödésétől eltér. A XIX. század közepéig lényegében kizárólag a belső viszonyok alakították, külső hatásoktól mentes tudott maradni. A kínai jogi kultúra magába foglal szokásjogi rítusokat, társadalmi normákat; a konfucianizmus tanításai visszatükröződnek benne, de ugyanúgy a legizmus, a marxista és leninista ideológia, valamint a szovjet jog egyes elemei, a nyugatról érkező, a kínai jogrendszerbe implementált újítások és a szocializmus jogi vívmányai is fellelhetők benne. Így egy nagyon komplex, különlegességekkel teli jogrendszerről beszélhetünk.

Kormány Attila ezt a teljesen egyedi jogrendszert olyan terminus technicusok használatával, valamint helyenként párhuzamok megvonásával mutatja be, amelyek a kontinentális jogi gondolkodással rendelkező szakemberek számára könnyebben érthetővé teszik ezt, a sajátjuktól markánsan eltérő, kivételes, kínai jogi gondolkodást. Ugyanakkor a keleti kultúrák iránt érdeklődők számára is érdekes lehet ennek a sajátos rendszernek a megismerése azáltal, hogy a társadalmi vetülete felöl közelíti meg a témát, annak erkölcsi, vallási és szokások terén megjelenő aspektusaira fókuszálva, a történelmi háttér kontextusaiba beágyazva. És azáltal, hogy érzékelteti a kínai történelem és a kínai jog szoros kapcsolatát, egymástól el nem választhatóságát, a történelmet kedvelökhöz is közelebb hozza a kínai gondolkodást, különösen a jogi vonatkozását.

Kínában a XX. század első felében kezdődtek azok a törekvések, amelyek a modern kínai jog testet öltéséhez vezettek. Egyes szerzők azt is vitatják, hogy ezt megelözően egyáltalán létezett-e modern európai értelemben vett jog Kínában. Ennek gyökere a szerző álláspontja szerint a ,jog” fogalmának eltérő meghatározásában keresendő. Ugyanis a kínai jogrendszer a jogot mint alanyi jogot nem is ismerte. A konfuciánus filozófia az egyénre mint erkölcsös emberre fókuszált, a tradicionális Kína vizsgálódási körében a jog nem kapott szerepet. A XX. század közepén, a jogrendszer kiépítése - vagy átformálása stagnált, ebben változás Deng Xiaoping vezetése alatt következett be, ugyanis ekkorra tehető a különféle nyugati jogintézmények beillesztése, meghonosítása a kínai jogrendszerbe egy teljes jogrendszert érintő jogalkotási reform következtében.

A kulturális forradalom után a kínai jogszabályok a nyugati mintát kezdték el követni. A jogi képzés alapjainak megteremtése és a modern bírósági rendszer létrejötte is erre az időszakra tehető. 1895-ben a Peiyang Egyetemen, Tianjinben megalakult az első, immár formális jogi képzést nyújtó fakultás. 
Érdekes megfigyelni, hogy amíg a modern, európai értelemben vett jog, jogrendszer kiépülése, a jogászképzés kialakulása meglehetősen későre datálható Kínában, a közigazgatási struktúra és jogrend keretei már i. e. 3. századtól léteztek, és kétezer évet meghaladóan szinte változatlan formában müködőképesek voltak. Ehhez képest, a nyugati kultúrákban a közigazgatás és a jog szorosan összekapcsolódik, a jogászképzésben jelentős részt kap a közigazgatási jog.

A kínai jogi rendelkezések jelenlegi formájukban amellett, hogy bizonyos tekintetben a történetileg kialakult szokásokhoz kötődnek, formálisan kizárólag Kínára jellemző sajátosságokkal átitatva, nyugati mintát követnek. A nyugati szabályok átvételének praktikus okai is vannak. A civil társadalom kiépülésének és a gazdasági növekedés biztosításának az eszközéül szolgálnak. Fokozatosan, de folyamatosan nő azoknak a rendelkezéseknek a száma, amelyeket nyugati kultúrákból vesz át a kínai jogrendszer, ezáltal a kínai jog „nyugatosodik". Így kerülhetett be a kínai jogrendszerbe a magántulajdon fogalma, de például az emberi jogok jogalkotási szinten történő elismerése is.

A szerző értékítéletet nem közvetít a müben arra vonatkozóan, hogy a kínai jogrendszer változása előnyös vagy hátrányos folyamat-e; objektíven vizsgálja ezeket az átalakulásokat. Olvasóként azonban arra az álláspontra lehet jutni, hogy ez a jogrendszert érintő fejlődési folyamat teljesen tudatosan történik, gondosan megválasztva, milyen mértékben és mely nyugati jogintézmények meghonosításából tud profitálni a kínai jog és társadalom. Továbbá a nyugati jogintézmények átvételén keresztül úgy tud alakulni a kínai gondolkodásmód, hogy alapvető fundamentumait megtartja, mégis képessé válik a nyugati kultúrákkal történő eredményes kommunikációra.

Összegzésképpen, úgy gondolom, a mű témaválasztásával egyedülálló, széles, diverzifikált olvasói kört képes megszólítani azzal, hogy különböző tudományterületek müvelői számára nyújt érdekes és értékes ismereteket. Külön kiemelem, hogy felsorolja azokat a kortárs, szakirányú müveket, amelyek a kínai jogtörténet egyes részeit, valamint a modern Kína jogrendszerét magyar nyelven dolgozzák fel. Így az olvasó iránymutatást kap, hogy ha jobban el szeretne mélyülni az ilyen jellegü részterületekben, akkor Salát Gergely müveihez tud fordulni az ókori Kína jogrendszerének a müködésével kapcsolatban, a császárkori Kínával kapcsolatban Kormány Attila, tehát a jelen könyv szerzőjéhez, a modern Kínával kapcsolatban pedig a Batzandan, Bóka János, Jordán Gyula és Koi Gyula által írt művekhez. 